\title{
A sense of self-suspicion: global legal pluralism and the claim to legal authority
}

\author{
Mariano Croce ${ }^{1 \star}$ and Marco Goldoni ${ }^{2}$ \\ ${ }^{1}$ Centre for Law and Cosmopolitan Values, University of Antwerp, Venusstraat 23, \\ Antwerp, Belgium; ${ }^{2}$ Glasgow Law School, The Square, Glasgow, United Kingdom
}

\begin{abstract}
Legal pluralism has become common currency in many contemporary debates on law and globalization. Its main claim is that a form of global legal pluralism represents both the most accurate description of law in times of globalization and the best normative option. On the descriptive level, global legal pluralism is considered more reliable than state-based accounts. On the normative level, global legal pluralism is understood as a possibility to open up the legal realm to previously unheard voices. This article assesses these claims against the background of classic legal-pluralist scholarship. After reconstructing the emergence of global legal pluralism and then examining its epistemic and normative versions, the last two sections identify the shortcoming of this approach by underlining the absence of what the authors call 'a sense of self-suspicion' in drawing the map of legalities in the global sphere. The main argument put forward is that global legal pluralism is oblivious of a few key insights offered by the founding fathers of classic legal pluralism.
\end{abstract}

Keywords: legal pluralism; global administrative law; liberal political theory; legal authority; symbolic power

Countless authors today seize upon the lexicon of pluralism and use bits and pieces of legal-pluralist scholarship to overcome the impasses of mainstream legal theories vis-à-vis the deep metamorphoses of domestic legal systems. The jargon of pluralism has become both the symptom of a failure and the signpost to a new mindset: the failure of grand legal narratives based on the assumption that the state is the condition of possibility for any orderly society, and the mindset of the new generation of legal theorists who do not completely disavow such legal narratives, but bemoan their incapacity to come to grips with today's globalized legal theatre. Yesterday's world was an archipelago of secluded islands with a legal order of their own; today's

*Correspondence to: Mariano Croce, Centre for Law and Cosmopolitan Values, University of Antwerp, Venusstraat 23, 2000 Antwerp, Belgium. Email: mariano.croce@libero.it 


\section{Croce \& M. Goldoni}

world is a structured skeleton of interconnected territories, where legal languages fuse, private orderings mushroom, and traditional, clear-cut vertical hierarchies give way to horizontal negotiations of different sorts. To account for the fuzziness of today's reality, a new vocabulary is needed, one that accommodates phenomena such as hybridity, ${ }^{1}$ indigeneity, ${ }^{2}$ interlegality, ${ }^{3}$ semi-autonomy, ${ }^{4}$ unofficiality, ${ }^{5}$ and others, nicely captured by the pluralist semantic repertoire. A strong, critical emphasis is placed by neo-pluralist authors on the thick substantialism of traditional constitutional theories, as these exhibit permanent traces of the outdated ideologies of nationalism and collectivism. With an eye to getting rid of static, monistic, centralistic understandings of law, neo-pluralist theories extol the multiplication of sources and the waning of vertical axes of command, and call for a resolute and full-hearted acceptance of the irretrievable hyper-pluralism of global legal reality.

However, if we go back to the forerunners of legal pluralism, we are faced with a different attitude. It can hardly be denied that former generations of pluralists were hasty in raising bold political claims and in leveling vociferous accusations at the hegemonic despotism of mainstream legal theories. Nevertheless, the theoretical arguments they put forward carried with themselves what might be called a 'sense of self-suspicion', which seems to be absent in contemporary theories. This sense of self-suspicion concerned the performative force that theories inevitably exert on their subject and the violence of conceptual categories which claim to be reporting matters of fact, whereas, in reality, they contribute to the production of these very facts. Accordingly, the main criticism that former legal pluralists made to that which they regarded as the myopia of state-centered theories was that the latter, whether wittingly or not, (also) pursued political goals and were (also) party to a political agenda: mainstream legal theories claimed to be describing a reality that they actively contributed to shaping in reference to the categories that the theories were producing and applying. In stark contrast with the professed allegiance to descriptive methods, mainstream legal theories tended to objectify and reify entities that, in several respects, were at odds with the categories produced at the theoretical level. This tendency was not due to the fact that mainstream legal theorists deliberately wanted to reify and objectify entities in order to justify the naturalness of something which had a fabricated character. Instead, the root of this tendency lay in the fact that theories always exert 'effects of reality' on what they account for. It is this basic premise that led former legal pluralists to be self-suspicious: Could it not be the case that they were inadvertently pursuing political goals, alternative to those of statecentered theories? Could it not be the case that pluralists' theoretical claims were inadvertently serving the purposes of another political agenda?

This awareness is plainly visible in some of the most compelling contributions to classic legal pluralism (hereinafter CLP), that is, Sally Falk Moore's inquiry into semiautonomous social fields, ${ }^{6}$ Sally Engle Merry's reconceptualization of legal pluralism, ${ }^{7}$ and Marc Galanter's analysis of indigenous law. ${ }^{8}$ With different intents and through different paths, their analysis of the relationship between the official and the unofficial elements of the legal phenomenon were meant to stress three key points that, all things considered, are shared by most erstwhile advocates of legal pluralism. 
First, theorists must be aware of their ethnocentric bent, whereby a given reality comes to be perceived and described through the homogenizing prism of a specific cultural tradition. Secondly, legal constructs as well as legal tools emerge out of a geohistorically bounded experience, much as legal theorists tend to project the conceptual contents of this experience on what falls outside its scope and to provide an account of the latter with the limited heuristic force of culture-specific paradigms. Thirdly, based on the first and the second points, the idea that there is such thing as the homolingual discourse of the law, which is able to penetrate all social interstices and to mould all social realities, is to be rejected. Law is not just one entity which can be described and encapsulated into a set of theoretical statements, but a complex frame where negotiations of different sorts take place, to the extent that one can hardly determine what law is in the here and now unless one pays due heed to how the actors involved make use of the law.

At the same time, the insights of these three pioneers of CLP shed light on the tendency of mainstream legal theories to de-historicize legal reality (which, needless to say, is the flip side of the concealment of the performative force of theorizing). State-centered legal theories tended to ignore that the tapestry of legal history is full of examples of legal regimes and juridico-political experiences which can hardly be squared with the allegedly universal categories deployed by legal theorists. However, such a lack of historical sensitivity had infiltrated the consciousness of legal theorists to such an extent that, when they spoke of legal experiences taking place outside the Western province, they were undecided as to whether non-Western populations had no law at all or had rudimentary forms of law. ${ }^{9}$ Be this as it may, this instinctive theoretical conviction was used as the basis to justify hierarchies in the alleged evolution from elementary to full-fledged legal systems. Moore, Galanter and Merry did nothing but voice the quasi-obvious claim that hierarchical visions of the law are not simply mistaken when it comes to non-Western contexts. Much more importantly, they hamper a sound understanding of Western legal systems. If the de-historicized, hierarchical vision of the law served as an ideological weapon, instrumental in the takeover of the legal field on the part of state institutions, ${ }^{10}$ it certainly made life harder for those who aspired to understand how law works in social life.

The issue we would like to tackle in this paper is whether or not the emerging strand of global legal pluralism (hereinafter GLP) can aspire to be the heir of CLP or, as we believe, is rather an updated version of conventional legal narratives, affixed to a liberal understanding of conflict. ${ }^{11}$ To achieve that, we will first address the nature of GLP and will then bring to light some of its drawbacks. Finally, we will explain why the exponents of CLP still have an important lesson to teach us when we approach the global legal and political scenario.

\section{THE EMERGENCE OF GLP}

As noted by many commentators, ${ }^{12}$ globalization, coupled with the rise of global governance, transnational law, and supranational law, has shaken the common understanding of law as essentially on a par with the sovereignty of the state. In effect, 


\section{Croce $\mathcal{E}$ M. Goldoni}

the current standard narrative interprets these developments in terms of a progressive decline of states' sovereignty. ${ }^{13}$ It should be noted that, while this descriptive statement does not concern directly the development of legal pluralism, it clearly points to the opening up of new possibilities for law and legal theory outside the framework of state law. The creation of supranational bodies (WTO, NAFTA, the EU and many others) and the increased mobility of capital, information, and people have put state-based understanding of legality under huge pressure. These developments have forced scholars to bring into question conventional accounts of political legitimacy and the legal order. ${ }^{14}$ GLP is a strand of pluralist thinking whose aim is to extend pluralist insights into the globalized legal realm in order to get rid of the traditional state-centrism of legal theory and to provide sounder knowledge of new legal phenomena. However, despite GLP's allegiance to the vocabulary of CLP, much of the latter's redemptive qualities have not been taken up.

The main concern of this new wave of pluralism is not with the subjection, colonization, or the exploitation of dominated populations of the Global South and the role official law plays in these processes. On the contrary, GLP's main preoccupation seems to be with how to make sense of existing legal networks, or better, networks comprised of entities whose legal or quasi-legal nature was already (de jure or de facto) acknowledged. Accordingly, issues arising outside the bounded realm of the national state have been treated either as a matter of governance or as a question of conflicts among different authorities. ${ }^{15}$ The former case is properly illustrated by the use of nonstrictly legal forms of regulation in the context of the governance on the Internet. Mainstream scholarship turned to alternative sources of regulation such as markets and architecture. ${ }^{16}$ The whole debate started by focusing on the question of controlling and disciplining, while its main focus was the interactions among citizens in the digital realm. In other words, the issues raised by new digital technologies (and the Internet in particular) have been managed as questions of governance of conduct based on the dogmas of regulation. By the same token, conflicts among authorities have been mostly regarded as cases of so-called 'same domain plurality', that is, cases where there are two or more authorities in the same domain of activity (or 'when more than one person/ body is authoritative for the same subjects in relation to the same field of activity ${ }^{17}$ ). In this context, some of the problems tackled by GLP, as we will explain in more detail below, remind of international private law and conflict of laws approaches.

An important factor to be taken into account for explaining GLP concerns the kind of controversies which inspired these legal theorists. They believed that the relations among supranational normative bodies as well as the relations among regional or subnational authorities should be understood as an actual instantiation of legal pluralism. ${ }^{18}$ In this way, international lawyers availed themselves of CLP scholarship as a toolkit to account for the realities of international and transnational legal orders. ${ }^{19}$ In this regard, to best penetrate GLP, it is important to juxtapose it with an alternative, authoritative approach to the proliferation and potential collisions among transnational legal bodies, namely, constitutional pluralism (hereinafter CP). ${ }^{20}$ This contrast will allow us to foreground the (truly pluralist) aspiration of GLP to overhaul the semantic repertoire of legal theory. Despite this, we will claim that a careful scrutiny of 
both reveal that neither CP nor GLP have severed the ties with classic state-based legal theory (and its limits). In the next two sections, CP and GLP will be explored so as to demonstrate that not only CP's answer, but also GLP's self-defined pluralist one is disappointingly misleading if assessed against the background of CLP. However, before proceeding further, a caveat has to be introduced at this stage. The following analysis will not take into consideration the current systemic approach to legal pluralism in its many versions ${ }^{21}$ because its methodology is based on partially different assumptions and it would not be possible to include this strand into the analysis in a coherent way. The attention paid by this stream of scholarship to global functional differentiation, alternative systemic rationalities, the importance of private and informal actors, and the proliferation of norm-creating sites, makes this approach impermeable to the criticisms leveled against GLP. ${ }^{22}$

\section{THE CONSTITUTIONAL VERSION OF LEGAL PLURALISM}

A first wave of thinkers who intended to give a pluralist twist to traditional legal theory emerged out of the need of coping with the porosity of state borders vis-à-vis supranational law and in particular in the case of European integration. The latter case is actually at the origin of CP. The multiplication of sites of authority within the European legal space was perceived as a controversial legal construction. This became even more pressing at the moment in which the Maastricht Treaty, along with the challenges it had to face vis-à-vis rising public and private actors, took the form of a $\mathrm{CP} .^{23}$ It was therefore the reaction of the German Constitutional Court to the claims contained in that Treaty that actually triggered the debate on this form of pluralism through a seminal article written by Neil McCormick. ${ }^{24}$ This was clearly interpreted as a case of conflict among authorities. McCormick resorted to an institutionalist theory of law in order to account for these ambiguous conflicts. ${ }^{25}$ What was considered as pluralistic about European integration was that the EU legal order (taken as an autonomous one) claimed to hold supremacy over national constitutions against the opinions of other national constitutional courts. Most of these claims were made by the European Court of Justice and other national constitutional courts in the course of deciding particular cases. ${ }^{26}$ Constitutional and legal theorists have taken these conflicts very seriously. ${ }^{27}$ Over 20 years, the reflections initially advanced by McCormick have been developed and unpacked by many other scholars and commentators in what has become an autonomous stream of contemporary legal theory. Neil Walker, the torch-bearer of this tradition, has offered an epistemic version of $\mathrm{CP},{ }^{28}$ which claims to be valid beyond the realm of EU constitutionalism. ${ }^{29}$ It should be noted that Walker does not rule out either the explanatory or the normative dimension of CP, for both flow from epistemic pluralism. ${ }^{30}$ Pluralism is first and foremost epistemic because it is a discourse shaped by and through the development of constitutionalism. Its main virtue lies in its being the least imposing perspective on other first-order points of view. The accent, again, is on the how of the constitutional discourse rather than on the what and the who. This is because, as a form of pluralist thinking, the constitutional pluralist discourse cannot impose substantial principles. It limits itself to providing a thin 


\section{Croce \& M. Goldoni}

meta-discourse as a shared discursive platform for all legal entities to interact meaningfully. The deep grammar of Walker's CP is based on the recognition of a set of seven standards that betray a specific and circumstantial genealogy. In fact, despite any allegiance to formal proceduralism, some of these standards do make reference to substantive contents, whereas others stem from the resolution of actual conflicts among existing legal orders. ${ }^{31}$ Finally, the other necessary requirement for this version of CP establishes that every constitutional site can claim 'internal sovereignty', but cannot claim any superiority vis-à-vis other constitutional sites. This means that the novelty of CP has to be seen in the absence of any claim of absolute or supreme authority. As a way to face the uncertainties generated by the lack of a supreme institution, Walker's project is to adapt the language and mindset of constitutionalism to the pluralist imperatives.

One might wonder why this discourse should successfully vindicate pluralism when no CP tenets can really ensure that new voices or new subjectivities can actually have access to the second-order discourse to which Walker makes reference. It is revealing that, in the end, this thin meta-discourse is compatible with standard forms of governance as those embodied, for example, by Comitology. ${ }^{32}$ While the interactions among different legal regimes can actually produce interesting outcomes in terms of legal reasoning and interpretation, nothing really ensures that a dialogue among these established institutions will be able to register voices and subjectivities that are not expressions of already constituted legal rationalities.

A different version of $\mathrm{CP}$, whose starting point and problems are basically the same adopted by Walker's but rests on substantive normative principles, is Mattias Kumm's. His argument is clearly underpinned by universalist tones, as it is based on the following assumption: the philosophical underpinnings of modern constitutionalism are always the same, despite the change of institutional design, because of the validity of certain principles that can be deduced with reference to the normative status of free and equal individuals. Against this larger background, traditional statecentered constitutional systems assume a more modest significance. Constitutionalism is decoupled from its state template and the state itself remains just one player in a wider stage. ${ }^{33}$ Based on this account, Kumm derives a set of universal constitutional commitments to the principles of legality, subsidiarity, democracy and rights-protection. In this reading, collisions among different normative claims are unavoidable because pluralists 'insist that the different legal orders making up the world of public law are not hierarchically integrated'. ${ }^{34}$ The absence of hierarchy and the recognition of the principles of autonomy and democratic selfgovernment bring about constitutional collisions and these compose the horizon of substantive CP.

The answer to these potential conflicts is inspired by the following approach:

[C] onstitutional pluralists insist that different legal orders don't simply coexist beside one another, as self-enclosed Leibnizian monads with at best contingent relationships between them. Notwithstanding the pluralist nature of legal practice, the relevant actors - and courts in particular - have established mechanisms and designed doctrines that allow for constructive mutual engagement between 
different legal orders. Legal pluralism [...] is guided, constrained, and structured in a way that justifies describing that practice in constitutional terms, even in the absence of hierarchical ordering. ${ }^{35}$

Kumm suggests dealing with them by resorting to a rationality which is immanent to the practice of modern constitutionalism. In particular, it is in the interplay among courts, understood as a communicative practice, that pluralism can find expression. At the same time, the reference to a common template imposes a limit on its antinomian tendencies. Moreover, in terms of adjudicative practices, pluralism can be managed through the application of the principle of proportionality. ${ }^{36}$ The latter is understood as the third stage of the balancing process where competing rights or principles are compared and assessed on the basis of a common scale. These two elements seem to indicate that pluralists defend an institutional conception of law (to be clear: one based on legal institutions) which shares some important features with a certain strand of legal positivism. More specifically, Kumm and other pluralists reject any hierarchy and therefore jettison both legal positivism and legal monism if these are understood (as in Hans Kelsen's pure theory) as conditions for the intelligibility of law. However, the identification of a common juridical space created by communication among courts and the emphasis on norm-applying institutions betray strong affinities with H.L.A. Hart's and Joseph Raz's conceptions of the legal system. ${ }^{37}$ From this perspective, one might reasonably question the pluralist nature of a type of constitutionalism which is so redolent with the grand theories of legal monism. Contrary to Walker's project, in this substantive type of CP the pluralist element emerges out of constitutional rationality and is therefore already contained and predetermined by the principles and rules inherited from modern constitutionalism. MacCormick corrected his original institutional pluralism by placing it under the banner of a higher law, that is, international law. ${ }^{38}$ On the same wavelength, Kumm subsumes pluralism under the higher norm of modern constitutionalism.

In this respect, both modes of CP aim to keep the tension between constitutionalism and pluralism alive and productive. Yet, given this aim, the promises of this strand of legal thought can be delivered only as long as none of the two elements prevail. Therefore, the risk involved in CP is that it will either be colonized by its constitutional tendencies or will simply be reduced to a form of constitutional plurality. In the latter scenario, it might well be the case that plurality turns out to be a way to register the incommensurability of claims between different authorities whose nature, however, will be determined on the basis of their belonging to an already existing orderly legal space. That way, the modern constitutionalist logic prevails over the pluralist aspects in such a way as to reinstate many tenets of legal monism. Despite any professed commitment to openness, a preference for closure and reduction to unity finally reappears. ${ }^{39}$

In the end, the advocates of CL tend to conflate pluralism with a legal scenario hallmarked by the absence of (institutional) hierarchies. In other words, these legal theorists identify pluralism with the lack of hierarchy before conflicting rules of 


\section{Croce $\mathcal{E}$ M. Goldoni}

constitutional supremacy which are to be excluded from the internal perspective of the sovereign state. In contrast with some of the traditional assumptions of legal positivists, constitutional pluralists celebrate the absence of a final arbiter having the last word. Nonetheless, they still accept as a platitude that pluralism is the outcome of the interaction among different legal institutions whose pedigree can be reconstructed according to formal sources of law. ${ }^{40}$

\section{NORMATIVE HYBRIDITY AND RADICAL GLP}

A spate of interesting works has been produced as a reaction to CP. Their starting point is the recognition that constitutionalism in the global age is caught in a Procrustean dilemma. ${ }^{41}$ More in particular, the supporters of GLP level two main criticisms. Firstly, from a heuristic standpoint, constitutionalism fails to account for the fragmentation of international and global law, in that it still holds onto some of the tenets of foundational constitutionalism (such as the idea of constituent power and the recognition of constitutional rights). Secondly, from a theoretical-political standpoint, when stretched to cover the new legal scenario, it is subject to the accusation of absence of legitimacy.

An attempt to overcome the limits of CP and to break the spell of modern constitutionalism has been recently pursued by Paul Schiff Berman and Nico Krisch.

Berman's methodology is based on the cultural approach to the study of law. ${ }^{42} \mathrm{He}$ starts off from Clifford Geertz's observation that law 'is part of a distinct manner of imagining the real'. ${ }^{43}$ Within this framework, law is part and parcel of the construction of social reality and its analysis cannot be detached from this aspect. The aim of this kind of enterprise is to retrieve how legal meaning (along with its condition of intelligibility) is produced rather than to test the criteria of legal validity. Moving from this basic assumption, Berman postulates that formal sources of law (on his account, state-based) do not exhaust the role of law in shaping social life. As a consequence, Berman praises CLP for being the only legal approach to law that takes into consideration the existence of a multiplicity of legal points of view. ${ }^{44}$ Legal pluralism is neither state-centered nor fully cosmopolitan (at least not in the universalist version of cosmopolitanism). The ideas of an ultimate legal authority and of state sovereignty (whether national or international) have to be abandoned precisely because they cannot be supported either by legal fictions or by factual monopoly of power. Global law and the proliferation of legal sites at the supranational level offer new incentives to fuel legal imagination and to foster the generative role of contemporary law.

Accordingly, the task of GLP is to offer a reconstruction of the legal meaning generated within these contexts. This leads Berman to the recognition that 'we live in a world of multiple overlapping normative communities'. ${ }^{45}$ This means that a multiplicity of legal orders are in principle legitimized to claim the right to regulate the same social field or the same activity. He defines this condition as normative or legal hybridity. No clear definition is provided for this notion, but it can be described as the phenomenon of the relationship among multiple communities and their 
decision makers' ${ }^{46}$ The examples offered by Berman are several: from state vs. state conflict to state vs. international norms and state vs. non-state law. Legal hybridity is first and foremost a de facto reality with which it is necessary to come to terms. Nonetheless, Berman's GLP is even more ambitious, as it advances stronger claims than merely descriptive ones. It is indeed a normative theory because it praises the virtues of a pluralist understanding of legal interactions. As Berman points out:

[W] need to realize that normative conflict among multiple, overlapping legal systems is unavoidable and might even sometimes be desirable, both as a source of alternative ideas and as a site for discourse among multiple community affiliations. ${ }^{47}$

What are the main virtues of this form of GLP? The first is epistemic. Recognizing the multiplicity of legal sources beyond the state entails respecting social groups as autonomous creators of law and acknowledging their legal impact. The second main virtue is that, according to Berman, this form of pluralism is empowering insofar as it creates new opportunities for contestation and creative adaptation. ${ }^{48}$ Berman believes that pluralism should help cope with the phenomenon of hybridity through procedural and not substantive means. Since normativity is pervasive and the production of legal meanings relentless, substantive principles have to yield to normative proceduralism. ${ }^{49}$ No agreement on the contents of substantive principles is indeed possible. The recognition of this state of affairs is a crucial step in the response to legal hybridity:

$[\mathrm{T}] \mathrm{o}$ create or preserve spaces for productive interaction among multiple, overlapping legal systems by developing procedural mechanisms, institutions, and practices that aim to manage, without eliminating, the legal pluralism we see around us. ${ }^{50}$

GLP is thus conceived as a tool for managing legal hybridity by devising procedures in which the voices of different communities can be heard. Berman claims that this approach is likely to tame conflicts among staunchly diverse and contrasting views of different legal orders. Much as Berman concedes that these procedures are not completely formal, he contends that they cannot decide any issue by introducing only substantive reasons. As noted by Alexis Galán and Dennis Patterson, this requirement not only weakens Berman's GLP, but makes it depend on a liberal political philosophy. ${ }^{51}$ Not every new voice is legitimate, but only those that put forward reasonable arguments. Berman's examples are quite telling, for they all point to interactions between different sites of authority or institutional power and rarely discuss informal (that is to say, social, not institutional) movements. Overall, Berman's GLP turns out to be an instrumental version of liberal pluralism whose main point is that institutional procedures must be devised to govern problematic interactions among different layers of legal orders. The fact that the interacting institutions do not have to be attached to state legal systems hardly makes Berman's theory an authentic specimen of legal pluralism.

A further (allegedly) radical version of GLP comes from the experience of global administrative law. In an effort to get rid of the normalizing and oppressive tenets of 


\section{Croce \& M. Goldoni}

modern constitutional law, Nico Krisch suggests the time has come to recognize that 'different layers of law in the postnational order no longer operate in separate spheres but are deeply intertwined'. ${ }^{52}$ Krisch's main contribution to this debate is that pluralism does not only serve as a prism for understanding the structure of law, for it also provides the best normative perspective. Such a radical GLP has three main virtues: revisability, contestation, and checks and balances. Revisability is ensured by the lack of ultimate authority and it marks the pluralist character of what Krisch defines as the 'postnational legal order', while checks and balances are operational through the proliferation of sites of authority. However, for our purposes in this article, contestation is the most interesting virtue. Openness to contestation is supposed to be the radical aspect of GLP and to ensure that accountability is properly in place in the interaction among different legal orders and institutions. Only through contestation is it possible to counter the lack of trust that is engendered by the absence of a direct representative link between supranational institutions and social agents, that is, between the governing supranational institutions and those governed. Moreover, only through contestation does it become possible for legal networks to register previously excluded voices.

In the light of Krisch's discussion of instantiations of contestation in GLP (e.g. genetically modified organisms disputes between the EU and the WTO, conflicts on security between $\mathrm{UN}$ and $\mathrm{EU}$ ) it might seem that he rather adopts a conflict-of-laws perspective. ${ }^{53}$ Nonetheless, his allegiance to GLP commits him to an admittedly stronger stance. The conflict-of-laws approach understands the relations between different legal claims as a conflict between autonomous orders with a neat distinction between inside and outside. ${ }^{54}$ GLP's starting point is different because it is concerned with orders that are intermeshed and interconnected, and accept forms of common decision-making. This is reflected in Krisch's terminology: interactions at the supranational level are not regulated by collision between norms, but by 'interface norms' which signal enmeshment and joint engagement in a common space. For courts, for example, this means to move from a self-perception as the guardians of their legal orders to the role of mediators or arbiters between orders, because they are party at one and the same time to many legal orders and therefore are at one and the same time the bearers of multiple identities.

In order to assess the nature of this kind of legal pluralism it is necessary to analyze the interface norms which are supposed to regulate the conflicts ensuing from different legal standpoints. Krisch states that interface norms are based on the principle of public autonomy:

[These norms] will also reflect other factors, such as the degree of prior formal acceptance of other norms (for example, through ratification), the proximity of values (for example, equivalence or identity in the interpretation of rights), or functional considerations, such as the utility of cooperation in a regime. Yet, these should be secondary factors, operating within the autonomy-based framework I have just outlined. If a polity has a strong autonomy pedigree, its norms are due respect even if they are based on distinct values or compliance with them does not have immediate benefits. ${ }^{55}$ 
In the face of it, a crucial question remains: How will different claims from various legal standpoints be adjudicated? Krisch's reliance on the principle of public autonomy reveals itself to be a liberal answer to the issue of pluralism. Conflict rules do not have an overarching legal character, but are 'normative, moral demands that find (potentially diverging) legal expressions only within the various sub-orders' ${ }^{56}$ How these demands are put forward and then channeled is a question which is left largely unexplored, except for the treatment of adjudicative processes. Predictably, Krisch's solution is very close to the one proposed by global administrative law. Courts and regulatory bodies are the best-suited agents for dealing with these conflicts for two reasons. First, basically it is a matter of institutional design. In the process of interpreting the law, courts often collect claims from different legal orders, which is less often the case in other institutional sites. The idea is that, by doing so, courts provide a common space that endows parties with a speaking position. Accordingly, contestation can take place and be articulated in keeping with a thin common grammar. The second reason is that legal interpretation provides a common language well-equipped for dealing with contestation. As a matter of fact, Krisch admits that judicial minimalism is often the right attitude to issues of social and political conflict relative to global governance. He suggests taking up a case-by-case evolutionary, but minimalist, approach to legal interpretation. Given that it is not always easy to reconcile conflicting claims, decisions should refrain from addressing principles and should be restricted to the circumstances of the particular case without developing any wider theory of law. While the original inspiration behind Krisch's GLP was the recognition of different actors through the judicial channel, ${ }^{57}$ the innovative aspect of this approach is that it creates new possibilities for actors in spheres from which they were previously excluded. Nevertheless, he says nothing about whether and to what extent the judicial language colonizes political action and obfuscates the visibility of alternative legalities. Despite the claims of being a theory of systemic pluralism, Krisch's concern for the structure of global governance and his emphasis on inter-institutional conflicts take the edge out of the approach.

As was the case with CP, both Berman's and Krisch's GLP fail to take up CLP's lesson. ${ }^{58}$ Both theories fall prey of a major concern with the structure of global governance and the maintenance of its order, and thus prove unable to address the issue of who recognizes what and which are the epistemic tools employed in the process of recognition.

\section{THE SYMBOLIC ASPECT OF NORMATIVE PHENOMENA}

The exponents of CLP are certainly more cautious about the emancipatory and redeeming force of the plurality of legal orders. With few exceptions, ${ }^{59}$ they by and large believe legal pluralism possesses nothing inherently progressive or obscurantist. If for the time being we leave aside relevant theoretical differences, we can see that they all generally consider pluralism as nothing other than the direct upshot of a better comprehension of legal phenomena. Yet, as far as the aim of the present article is concerned, their commitment to non-evaluative accounts provides the grounds for 


\section{Croce \& M. Goldoni}

raising a misgiving: What if the access to the arena where legal orders are recognized as such, and thus can freely compete and interact with one another, is not as open as global legal pluralists appear to believe? In the light of this misgiving, the crucial question is what normative orderings qualify as legal orders and thus can claim to get access to the global arena as legitimate players. All in all, if it is the very access to the global arena that makes a legal order a legitimate player, then this access comes to exert legitimizing effects on legal orders. What if this access, after all, ends up ratifying the status quo where powerful and well-equipped legal orders mutually recognize each other and perform an activity whereby they decide who can join the club? To put it bluntly, are the organized collectivities of South-American peasants, or the mobilizing groups of dispossessed land-tenures, to be regarded as legitimate legal players in the field of global law? Most likely, most advocates of GLP would quickly provide an affirmative answer. The key question, however, is if the theory they develop allows them to do so from a conceptual viewpoint. We believe it does not.

This question has a symbolic significance that, in our interpretation, GLP tends to neglect. ${ }^{60}$ To tackle it we would like to go back to the issue we raised at the very outset, that is, the degree of self-suspicion that characterizes one's theory. It is worth relying on some key authors of CLP who have been alert to the relevance of this issue since the very beginning of the debate on legal pluralism. In our reading, in their writings two key aspects are given particular emphasis.

The first aspect is the theoretical instrument with which the legal character of a normative ordering can be ascertained. In the 1970s and the 1980s the debate over legal pluralism revolved around the question of what can be properly defined 'law' and what normative entities should be attributed the qualification of 'legal'. Famously, the same question was haunting legal philosophy, where scholars were concerned with the Hart-Kelsen and above all the Hart-Dworkin debates. ${ }^{61}$ However, a crucial difference between the two types of investigation should be stressed. In keeping with the project pursued by John Austin, one of the founding fathers of jurisprudence, legal philosophers aspired to discover the "key to the sciences of jurisprudence and morals ${ }^{32}$ in order to establish once and for all what law in general is. By doing so, they were hoping to be able to determine what makes a given system legal, irrespective of cultural and geo-historical differences. Quite the reverse, legal anthropologists who wanted to penetrate the way of life of non-Western populations were concerned about potential distortions introduced by a Westernbiased, culture-specific theoretical toolkit. The use of the jurisprudential lexicon available at the time, whose main elements were, for example, rules, authority, system, and coercion, ran the risk of projecting on the observed social realities something that the latter had neither knowledge nor experience of. Anthropologists feared the illusion of a theoretical projection whereby they could make sense of an observed population with tools that were completely alien to it. The result would be a distorted, unreal portrayal of the observed population, which reflected the convictions of the observer rather than the concrete dynamics of the population. 
Paradoxically, legal pluralists' preoccupation with this risk is attested by one of the fiercest critiques of CLP, Simon Roberts's Against Legal Pluralism. ${ }^{63}$ In this short but robust article, Roberts aims to debunk the need for such a thing as a pluralist view of law as he claims it is a distortion introduced by lawyers. Lawyers see law everywhere and are prone to believe that every normative entity involving rules and procedures should be defined as 'legal'. In doing so, they neglect some key aspects of both Western law and non-Western normative repertoires. In reality, such a concern has crossed the history of 20th-century social sciences, since it has to do with the fine line between observation and objectivation. The glance of the observer as well as the model of the theorist always risk reifying a given entity by investing it with the presuppositions that nurture the observer's and the theorist's approach to reality. Both the observer and the theorist tend to superimpose what Pierre Bourdieu calls a 'logic' or a 'generative formula', that is to say, a set of independent and coherent axioms that they elaborate to make sense of their object of study. ${ }^{64}$

Whether or not this critique is applicable to some formulations of legal pluralism (and most likely it is), the persistence of this debate among legal anthropologists attests to their sensitivity to this issue. Most of them believed that the perils of a theoretical colonization on the part of Western scholarship should be avoided with recourse to alternative instruments of inquiry. Claiming that all normative orderings were legal merely because they possessed rules, authorities and procedures could get them to obliterate important nuances. This is why two tutelary deities of legal pluralism like Moore and Merry were adamant that some sort of distinction between state law and other normative phenomena should be preserved. Moore avers that, much as there might be striking similarities between state law and a given normative ordering, 'there are occasions when [...] it may be of importance to distinguish the sources of the rules and the sources of effective inducement and coercion'. ${ }^{65}$ Merry believes 'it is essential to see state law as fundamentally different [from all other types of social ordering] in that it exercises the coercive power of the state and monopolises the symbolic power associated with state authority. But, in many ways, it ideologically shapes other normative orders as well as provides an inescapable framework for their practice'. ${ }^{66}$

Some more radical advocates of CLP have interpreted these remarks as a reversion to a centralist view. ${ }^{67}$ We rather believe that these junctures bespeak a major concern as to the risk that a theory might claim to possess all that is necessary to determine what law is and what is not regardless of cultural and geo-historical variables: such an abstractive approach could induce the theorist to draw up (whether inadvertently or not) a list of admissible candidates. In other words, Moore's and Merry's is a methodological caveat. This positively impacted on CLP, where scholars were conscious from the very beginning of the risks of objectification, whether they espoused an extreme or a milder pluralism. This leads us to discuss the second aspect brought into light by prominent representatives of CLP. In fact, this methodological caveat is inextricably linked to the aspect of symbolic power. While discussing the differences between state law and other normative orderings, Merry points out 'it is essential to see state law as fundamentally different in that it exercises the coercive 


\section{Croce \& M. Goldoni}

power of the state and monopolizes the symbolic power associated with state authority' ${ }^{68}$ This juncture lays bare the key relation between material and symbolic power, whereby state's monopoly on force is not as important in terms of menace and dissuasion as it is in terms of people's perception of something as law. In other words, a pivotal element for a normative ordering to be legal is the general perception of its pre-emptive character. If this is true, then the source of law's capacity to override the rules of other normative orderings does not lie in its normative structure. For it is a much more complex process - external to the normative structure of law in terms of rules and procedures - that confers a legal value on a specific normative ordering.

This point is stressed by Marc Galanter when he claims that the way in which the label 'law' is used can be subject of controversy. His argument reads as follows: legal reality is by no means a homogeneous body of rules and procedures established by state agencies. As Galanter reveals with reference to many actual cases and disputes where the law is hardly or partially involved, the area where the law develops and lives is composed of partially self-regulating fields or sectors, organized along spatial, transactional or ethnic-familial lines, ranging from primary groups in which relations are direct, immediate and diffuse to settings in which relations are indirect, mediated and specialized. Galanter's suggestion is a refined one. He does not claim that the use of the label 'law' is straightforwardly arbitrary or mistaken. He maintains that using 'law' for distinguishing between official and unofficial orderings in a particular geohistorical context is always the outcome of a struggle over meaning in which there are winners and losers, and where the group of losers is composed of all those unofficial orderings which might be properly seen as having a 'law' but are considered as unofficial due to the primacy of their rivals. In this light, Galanter eventually concludes that Western state legal systems are nothing other than institutionalintellectual complexes' that claim 'to encompass and control all the other institutions in the society and to subject them to a regime of general rules [...]. These complexes consolidated and displaced the earlier diverse array of normative orderings in society, reducing them to a subordinate and interstitial status' ${ }^{69}$

\section{THE POLITICS OF DEFINITION}

Based on the analysis above, what makes GLP a radical form of liberalism rather than the genuine heir of CLP is a basic concern with the symbolic power of definition. The idea that in the global theatre every form of ordering can in principle lay a claim to legal authority over a given field or population neglects the issues of who has the material and symbolic power to lay this claim, what the sources of this power are, and in what ways this claim could and should be raised. A serious worry is that the primary source of this power is the very same ordering's ability to 'speak' the language of global law and to have its claim heard by the actors who are already recognized as legitimate legal players. More in particular, the supposition that an ordering's claim to have some sort of legal authority is a neutral one is flawed, since those who claim legal authority are de facto required to agree on the jargon that makes 
their claim intelligible, and thus to use this jargon to couch their stance. In this respect, it is worth mentioning an example discussed by Gordon Woodman in a pithy defence of CLP apropos of the relationship between colonial laws and pre-colonial customary practices. Woodman writes:

Towards the end of the nineteenth century the British colonial government proposed that vacant, unowned lands should be vested in the British Crown. The proposal was resisted by local interest groups. To make the resistance politically effective, it was necessary to express the grounds of opposition in terms which would accord with the law of the colonial state. It appears that the representatives of the indigenous communities then restated their customary laws to claim that the communities themselves were the owners of land which was currently unoccupied and unused. The owner of any such land was the nearest community, it was said, and where an area of unused land lay between two communities, there was under customary law a common boundary running midway between their settlements. And so there was invented a doctrine of customary law which held that there was no unowned land. The argument was politically successful and the proposal to vest vacant lands in the Crown was abandoned. It seems clear that the threat had led to a reformulation of customary law in terms which were remote from the norms observed in practice. ${ }^{70}$

On the one hand, this example intends to exalt the flexibility of normative regimes and their capacity to adapt to mutable circumstances. This image of normativity can well be squared with GLP's celebration of the morphing nature of normative practices, which are getting out of the bounded sphere of state system and are taking unpredictable configurations. On the other hand, however, to engage in the successful negotiation described by Woodman, the customary practice had to yield to the law of the colonizers. The population had no vocabulary of its own to claim possession of the land and had no idea whatsoever of Western property rights. In the end, the only possibility for the colonized population to make their case was to adopt the lexicon of colonial law - one that was alien to their indigenous experience - and to subsume their normative categories regime under the categories of English law. In this small-scale theatre, the weak and worse-off actually voiced a strong claim through law and turned out to be successful. But success came at a price. ${ }^{71}$

When assessed against the background of CLP, it is evident that what GLP omits to bring into question is the very legal frame, or rather, the instruments, language, procedures and categories that allow such thing as legal pluralism to exist. In doing so, GLP takes the legal for granted, whereas 'the legal' is already a politically, nonneutral approach to the bare reality of conflicts. The pluralism that the advocates of GLP speak of is always-and-already addressed as legal, with the politically cumbersome consequence that only those who qualify as legal actors can have a say in the legal discourse. GLP's failure to account for what comes before a legal-pluralist scenario is put in place, or rather, its tendency to regard the plurality of laws as a social datum is on a par with traditional legal positivists' tendency to search for legal systems in non-Western indigenous realities and to measure their degree of civility on that basis. Both see their tendency as open-minded, universalistic and progressive, 


\section{Croce $\mathcal{E}$ M. Goldoni}

while neither realize that their very approach to social reality makes certain entities invisible and theoretically unspeakable.

In conclusion, CLP still serves as a noble warning about the lack of self-suspicion. It urges legal and political theorists to adopt a doubly critical approach: to their subject and to the lens through which they look at it. In this respect, CLP should rather be regarded as a critical exploration into the tacit presuppositions of one's theorizing, which orients and prompts one's analysis to emphasize certain aspects and to overlook others. If this is so, then it does make sense, at least at present, to pit CLP against GLP.

\section{ACKNOWLEDGEMENTS}

The authors thank the Editor and the three anonymous reviewers of Ethics and Global Politics for their careful reading of the manuscript and their comments. Although this article is the fruit of a unitary and jointly discussed project, Mariano Croce wrote Sections 1, 5, and 6, while Marco Goldoni Sections 2, 3 and 4.

\section{NOTES}

1. Seán P. Donlan, 'Remembering: Legal Hybridity and Legal History', Comparative Law Review 2 (2011): 1-35.

2. Marc Galanter, 'Justice in Many Rooms: Courts, Private Ordering, and Indigenous Law', Fournal of Legal Pluralism and Unofficial Law 19 (1981): 1-47.

3. Boaventura de Sousa Santos, 'Law: A Map of Misreading. Toward a Postmodern Conception of Law', fournal of Law and Society 14, no. 3 (1987): 279-302.

4. Sally F. Moore, 'Law and Social Change: The Semi-Autonomous Social Field as an Appropriate Subject of Study', Law and Society Review 7 (1973): 719-46.

5. Masaji Chiba, Legal Pluralism: Towards a General Theory Through Fapanese Legal Culture (Tokyo: Tokai University Press, 1989).

6. Moore, 'Law and Social Change'.

7. Sally E. Merry, 'Legal Pluralism', Law E Society Review 22, no. 5 (1988): 869-96.

8. Galanter, 'Justice in Many Rooms'.

9. See in particular the criticisms addressed to H.L.A. Hart's legal positivism in Anthony N. Allott, The Limits of Law (London: Butterworths, 1980); and Morton Horwitz, 'Why is Anglo-American Jurisprudence Unhistorical', Oxford fournal of Legal Studies 17 (1997): 551-86.

10. Based on a pluralist understanding of law, some scholars have depicted the transition from the Ancien Régime to the system of autonomous and independent states in terms of jurisdictional conflicts among the rising governmental elites and a plethora of former authorities endowed with a combination of juridical and political powers. See Lauren Benton and Richard Ross, eds., Legal Pluralism and Empires, 1500-1900 (New York: New York University Press, 2013).

11. It is important to note that, by saying 'the heirs', we do not mean to make a case against the use that global legal pluralists make of the label 'legal pluralism'. In other words, we do not want to impose restrictions on the use of this or other labels, nor could we ever claim to have the legitimate authority to do so. Rather, our theoretical point is that, within the general framework of GLP, the term 'pluralism' gets impoverished, because - as will become clearer at the end of the article - the plurality that its advocates talk about is composed of voices that have the (material and symbolic) means to have a say in the global legal theatre. Accordingly, 
we argue that the 'P' in GLP has a different connotation than the 'P' in CLP. Read against this background, it is our contention that global legal pluralists can certainly claim they are genuinely pluralist, but cannot claim, as many of them actually directly or indirectly do, that they are iterating the meaning of pluralism that classic legal pluralists had in mind. This is both a theoretical and an interpretative argument that basically aims to spell out the meaning that the term 'pluralism' assumes within different theoretical contexts.

12. See in particular the extensive analysis provided in William Twining, General furisprudence. Understanding Law from a Global Perspective (Cambridge: Cambridge University Press, 2009).

13. It is actually far from clear whether globalization had a negative impact on states' sovereignty or simply transformed the nature of the state. Cf. Chris Bickerton, European Integration (Oxford: Oxford University Press, 2012).

14. For two recent examples, see Keith Culver and Michael Giudice, Legality's Borders (Oxford: Oxford University Press, 2010); and Nicole Roughan, Authorities (Oxford: Oxford University Press, 2013).

15. Pluralist echoes can be found in many of the works devoted to multilevel governance or (which is different) multilevel constitutionalism. See e.g. Simona Piattoni, A Theory of Multilevel Governance (Oxford: Oxford University Press, 2010); and Ingolf E. A. Pernice, 'The Treaty of Lisbon: Multilevel Constitutionalism in Action', Columbia fournal of European Law 15, no. 3 (2009): 349-407.

16. The classic reference goes to Lawrence Lessig, Code and Other Laws of Cyberspace (New York: Basic Books, 1999).

17. Roughan, Authorities, 46.

18. For a relatively optimistic introduction to these issues see Sabino Cassese, 'Administrative Law without the State? The Challenge of Global Regulation', New York University fournal of International Law and Politics 37 (2005): 663-94; more recently, see Neil Walker, Intimations of Global Law (Cambridge: Cambridge University Press, 2014).

19. For an overview, see Ralf Michaels, 'Global Legal Pluralism', Annual Review of Law and Social Science 5 (2009): 243-62.

20. For a similar distinction see Andre Nollkaemper, 'Inside or Out: Two Types of International Legal Pluralism', in Normative Pluralism and International Law, ed. Jan Klabbers (Cambridge: Cambridge University Press, 2013), 95. For an overview of CP, see Christine E. J. Schwöbel, 'The Appeal of the Project of Global Constitutionalism to Public International Lawyers', German Law fournal 13 (2012): 1-22.

21. See e.g. Gunther Teubner, Constitutional Fragments (Oxford: Oxford University Press, 2012); and Graaf Callies and Peer Zumbansen, Rough Consensus and Running Code (Oxford: Hart, 2010).

22. We would like to thank an anonymous reviewer for drawing our attention to the different take on pluralism adopted by this stream of scholarship. For a vivid example see Peer C. Zumbansen, 'Transnational Legal Pluralism', Transnational Legal Theory 10, no. 2 (2010): 141-89.

23. For an accurate overview of the debate see Jan Komarek and Matej Abelj, eds., Constitutional Pluralism in the European Union and Beyond (Oxford: Hart, 2012).

24. Neil MacCormick, 'Beyond the Sovereign State', The Modern Law Review 56 (1993): 1-18.

25. For a last statement on his own institutional theory of law see Neil MacCormick, Institutions of Law (Oxford: Oxford University Press, 2007).

26. To sum up, the European Court of Justice has made three claims to supremacy: first, that within its area of competence, European law has supremacy over all conflicting rules of national law, including the constitution; second, the ECJ has exclusive competence to decide what counts as a matter of European law, that is, what falls within its competence (kompetenz-kompetenz); third, that it has ultimate authority to decide all matters on 
European law. On the national side of the judicial divide, both the first and second of these claims have been challenged.

27. Mattias Kumm, 'Who Is the Arbiter of Constitutionality in Europe?', Common Market Law Review 36 (1999): 351-86.

28. Neil Walker, 'The Idea of Constitutional Pluralism', The Modern Law Review 65, no. 3 (2002): 317-59, at 339 .

29. Ibid.

30. On this point, see the clear reconstruction by Jaklic Klemen, Constitutional Pluralism in the EU (Oxford: Oxford University Press, 2014), 58-9.

31. For example, the fourth standard tenet establishes the requirement of interpretive autonomy, a claim 'to the entitlement of an organ internal to the polity or political process to construe the meaning and extent of these competences' and the fifth requires that 'there is the constitution and regulation of an institutional structure to govern the polity'. See Walker, 'The Idea of Constitutional Pluralism', 342.

32. The Comitology system creates inclusive decision-making contexts which allow for mutual accommodation and mutual learning between different types of supranational and nonaligned actors [Neil Walker, 'Late Sovereignty in the European Union', in Sovereignty in Transition, ed. Neil Walker (Oxford: Hart, 2003), 30].

33. Mattias Kumm, 'The Best of Times and the Worst of Times: Between Constitutional Triumphalism and Nostalgia', in The Twilight of Constitutionalism?, eds. Petra Dobner and Martin Loughlin (Oxford: Oxford University Press, 2009), 201-20.

34. Mattias Kumm, 'The Moral Point of Constitutional Pluralism', in Philosophical Foundations of European Union Law, eds. Julie Dickson and Pavlos Eleftheriadis (Oxford: Oxford University Press, 2012), 216.

35. Ibid., 217.

36. Mattias Kumm, 'Institutionalising Socratic Contestation: The Rationalist Human Rights Paradigm, Legitimate Authority and the Point of Judicial Review', European fournal of Legal Studies 1, no. 2 (2007), 1-32.

37. See Raz's definition of a legal system as requiring at least one necessary kind of institutions, to wit, norm-applying institutions: Joseph Raz, Practical Reason and Norms (Oxford: Oxford University Press, 1975), 122-5.

38. Neil MacCormick, 'Risking Constitutional Collision', Oxford Fournal of Legal Studies 18 (1998): 517-32.

39. Emilios Christodoulidis, 'Law and the Framing of Civil Society', European Law fournal 9, no. 4 (2003): 401-32.

40. This seems to be the view adopted by Culver and Giudice, Legality's Borders.

41. Nico Krisch, 'Global Administrative Law and Constitutional Ambition', in The Twilight of Constitutionalism?, eds. Petra Dobner and Martin Loughlin (Oxford: Oxford University Press, 2009), 245-66.

42. Paul Schiff Berman, 'Telling a Less Suspicious Story', Yale fournal of Law and Humanities 13, no. 1 (2002): 95-139.

43. Clifford Geertz, Local Knowledge: Further Essays in Interpretive Anthropology (New York: Basic Books, 1983), 184.

44. See his monograph Paul S. Berman, Global Legal Pluralism. A furisprudence Beyond Borders (Cambridge: Cambridge University Press, 2012); see also Paul S. Berman, 'The Globalization of Jurisdiction', University of Pennsylvania Law Review 151 (2002): 311-529; and Paul S. Berman, 'A Pluralist Approach to International Law', Yale fournal of International Law 32 (2007): 301-22.

45. Berman, Global Legal Pluralism, 3.

46. Ibid., 117. 
47. Paul S. Berman, 'Global Legal Pluralism', Southern California Review 80 (2007): 1155-237, at 1155 .

48. Berman, Global Legal Pluralism, 118.

49. Alexis Galán and Dennis Patterson, 'The Limits of Normative Legal Pluralism', International fournal of Constitutional Law 11, no. 3 (2013): 783-800, at 786.

50. Berman, Global Legal Pluralism, 10.

51. Galán and Patterson, 'The Limits of Normative Legal Pluralism', 787.

52. Krisch, Beyond Constitutionalism, 297.

53. The standard version of this approach is Christian Joerges, 'Sozialstaatlichkeit in Europe: A Conflict-of-Laws Approach to Law of the EU and the Proceduralisation of Constitutionalisation', German Law fournal 10 (2009): 335-60.

54. For an analysis of the EU as comprised of many autonomous legal systems see Julie Dickson, 'Toward a Theory of European Union Legal Systems', in Philosophical Foundations of EU Law, eds. Julie Dickson and Pavlos Eleftheriadis (Oxford: Oxford University Press, 2012), 25-53.

55. Krisch, Beyond Constitutionalism, cit., 296.

56. Ibid., 296.

57. A similar approach had been already advocated by Francis Snyder, whose analysis of global legal pluralism is based on the emergence and development of a plurality of sites of governance through the strategic action of economic players across boundaries. See Francis Snyder, 'Governing Economic Globalisation: Global Legal Pluralism and European Law', European Law Fournal 5 (1999): 334-74.

58. In the limited context of the present article we cannot address remarkable proposals of authors who advance a different understanding of what a global law should be like vis-à-vis existing differential of powers among legal actors. This is the case of scholars who speak of a global law 'from below' and claim that alternative voices (in particular those of the worseoff) should be viewed as respectable and, to some extent, influential legal actors. The idea of a global law from below as well as human rights from below should be regarded as an invitation to take the ambiguities of international norms seriously and to decipher both their virtues and their downsides. The champions of global law from below claim that to produce a weapon that is both effective in the neo-colonial war and able to mobilize resources at the bottom end of the social scale scholars should assess the impact of global legal instruments case by case. On this account, this type of 'juris-globalism' cannot be likened to the types of GLP we have presented so far, nor can it be charged with the same flaws. Nonetheless, we believe that it amounts to a particular evolution of CLP and that therefore it would be incorrect to look at it as a form of global legal pluralism, at least in view of the meaning that this latter label has taken in the last years. For this reason, an analysis of these relevant contributions would exceed the limits of our argument in this article. Relevant works in this area of legal studies are: Boaventura de Sousa Santos and Cesar A. Rodríguez-Garavito, eds., Law and Globalization from Below: Towards a Cosmopolitan Legality (Cambridge: Cambridge University Press, 1995); Mark Goodale and Sally Engle Merry, eds., The Practice of Human Rights: Tracking Law Between the Global and the Local (Cambridge: Cambridge University Press, 2007); Balakrishnan Rajagopal, International Law From Below: Development, Social Movements and Third World Resistance (Cambridge: Cambridge University Press, 2003); and William Twining, ed., Human Rights: Southern Voices (Cambridge: Cambridge University Press, 2009).

59. For one thing, John Griffiths's seminal article on the nature of legal pluralism might be regarded as a critique of the colonization of law schools by a state-centric idolatry (see John Griffiths, 'What is Legal Pluralism?', Fournal of Legal Pluralism and Unofficial Law 24 (1989): 1-55). Therefore, he believes pluralism does justice to neglected legal realities. There is no 
doubt that Griffiths's passionate harangue against legal monism betrays, as it were, a political stance.

60. It is worth noting that we are comparing works that belong to remarkably different epochs. In this light, a straightforward accusation of an un-self-conscious adoption of hegemonic frameworks might come across as unfair. Likewise, the different geo-political scenarios that the representatives of CLP and GLP have before their eyes lead them to adopt different theoretical strategies. This is why one might reasonably say (as one of the anonymous reviewers did) that GLP advocates' effort to participate in a discourse about institutional design cannot be portrayed as a bare disposal of the critical stances of CLP. However, our thesis is not that the advocates of GLP intentionally refuse to embrace a critical attitude to law and legal theory in order to espouse the hegemonic legal jargon. Quite the reverse, our concern is with how the hegemonic jargon of legal theory (based on the conception of law we have alluded to in the previous sections) comes to assimilate alternative lexica and to hollow them out of their critical force. Hence, our target is not so much the conscious intention of GLP authors, who advance significant contributions to legal and political theory, as the way in which a given characterization of the law ends up colonizing the conceptual repertoire of legal pluralism and lessening its critical force.

61. On the former, see Torben Spaak, 'Kelsen and Hart on the Normativity of Law', in Perspectives on Furisprudence. Essays in Honour of Fes Bjarup, eds. Peter Wahlgren and Mauro Zamboni (Stockholm: Stockholm Institute for Scandinavian Law, 2005), 397-414; on the latter see Scott Shapiro, 'The 'Hart-Dworkin' Debate: A Short Guide for the Perplexed', in Ronald Dworkin, ed. Arthur Ripstein (Cambridge: Cambridge University Press, 2012), 22-55.

62. John Austin, The Province of Furisprudence Determined (Cambridge: Cambridge University Press, 1995), 21.

63. Simon Roberts, 'Against Legal Pluralism. Some Reflections on the Contemporary Enlargement of the Legal Domain', Fournal of Legal Pluralism 42 (1998): 95-106. For a more recent work on the same wavelength, see Simon Roberts, 'After Government? On Representing Law without the State', The Modern Law Review 68, no. 1 (2005): 1-24.

64. Pierre Bourdieu, The Logic of Practice (Stanford, CA: Stanford University Press, 1980), 35.

65. Moore, 'Law and Social Change'.

66. Merry, 'Legal Pluralism', 879.

67. Franz Von Benda-Beckmann, 'Comment on Merry', Law E Society Review 22, no. 5 (1988): 897-901; and Gordon R. Woodman, 'Ideological Combat and Social Observation. Recent Debate about Legal Pluralism', fournal of Legal Pluralism 42 (1998): 21-59.

68. Merry, 'Legal Pluralism', 879.

69. Galanter, 'Justice in Many Rooms', 19.

70. Gordon R. Woodman, 'Diritto consuetudinario e diritti consuetudinari: una considerazione comparativa sulla loro natura e sulle relazioni tra tipi di diritto', Politica E Società 2 (2009): 91-107, at 105-106 (emphasis added). See also Gordon R. Woodman, Customary Land Law in the Ghanaian Courts (Accra, Ghana: Ghana Universities Press, 1997), Chap. 2.

71. We should like to note that Berman is aware of this risk, as he regrets that, in order to make their voices heard, some entities must translate their claims into a dominant discourse. However, we believe that this awareness does not suffice to redeem the critical force of legal pluralism. As the advocates of global law from below, or cosmopolitanism from below, or human rights from below illustrate (see fn. 58), there are many ways to make the voice of the worst-off heard without adhering (at least full-heartedly) to a hegemonic platform. 